\title{
'CATCHING THE EEL' - DOCUMENTARY EVIDENCE FOR CONCEPTS OF THE ARABIC BOOK IN THE MIDDLE PERIOD
}

\author{
Konrad Hirschler \\ SCHOOL OF ORIENTAL AND AFRICAN STUDIES, UNIVERSITY OF LONDON
}

This article reflects on the concept of the 'book' in the Middle Period (fifth/eleventh to early tenth/sixteenth centuries). On the basis of a seventh/thirteenth-century library catalogue from Damascus it discusses how contemporaries faced the challenge of defining what a book actually was. Focusing on the catalogue's section on composite manuscripts $\left(m a g \bar{a} \bar{a} m \bar{l}^{c}\right)$ it suggests that this document's writer employed two - ultimately irreconcilable - definitions of a book: the book as a discrete textual item (taking the title as the main criterion) and the book as defined by its physical shape. This writer's cataloguing practices illustrate the fluid nature of the 'book' well beyond the Formative Period between the first/seventh and the fourth/tenth century.

At a time when the book as a physical object with a stable text is losing ground to digital files with more fluid textual formats, it seems pertinent to reflect on what a 'book' was understood to be in a pre-print, manuscript culture. ${ }^{1}$ For contemporaries in the Middle Period coming up with a single definition of the book was as elusive as any attempt to catch Luther's proverbial eel. ${ }^{2}$ The present discussion takes a specific documentary example from the Middle Period in order to problematise the concept of the Arabic book. The choice of the Middle Period is informed by the chronological profile of modern scholarship on cultural history that has - as in so many other fields - put the two traditional foci of Middle Eastern historical studies on the main stage: the Formative Period of Islam until the fourth/tenth century and the Modern Period from the nineteenth century onwards. The Middle Period, however, has been neglected in most discussions of the Arabic book's development between these 'classical' and 'modern' eras. Consequently, the most authoritative recent overview of the history of the book in the Muslim lands has little to say about the period between the fifth/eleventh and tenth/sixteenth

1 I thank Antonella Ghersetti for inviting me to contribute to this volume as well as the reviewers for their insightful comments.

2 Referring to Luther's description of the elusive Erasmus as 'the eel whom only Christ could catch' and who could be all things to all men (Luther's Works, vol. 54, 19; cf. N. Housley, Contesting the Crusades). 
centuries. ${ }^{3}$ Discussions that have touched upon the Middle Period, such as Pedersen's The Arabic Book and Rosenthal's 'Of Making Books There Is No End', are often grounded in the Formative Period and confidently apply a single concept of the book to a period stretching from the second/eighth to the ninth/fifteenth centuries. ${ }^{4}$

Studies such as those by Günther, Toorawa and Touati, to name but the most recent, have discussed in detail the gradual development of a 'writerly culture', to borrow Toorawa's term, in the first Islamic centuries, especially its interplay with oral and aural practices. ${ }^{5}$ Schoeler's work is particularly relevant for the present discussion as he has shown the inherent fluidity of textual formats during the Formative Period. Of particular importance is his differentiation between hypomnema, that is to say draft notes, notebooks and written records that were not independent manuscript-books and actual manuscript-books (syngramma) that writers intended for wider circulation. ${ }^{6}$ This discussion of the fluid format of the written text during the early Islamic period finds its counterpart in scholarship on the gradual introduction of printing in the Arabic-speaking lands from the eighteenth century onwards. Here, the transformation of the book's physical shape has again led to reflections on what a manuscript-book actually was. ${ }^{7}$

At first glance the question of what contemporaries during the Middle Period understood to be a book might seem unproblematic as this period's authors widely employed the term kitāb whenever they referred to the written word. However, if we turn to the period's narrative sources we see that a variety of concepts existed for textual units that do not sit easily with a commonsense understanding of a book. For instance, authors who referred to the number of books in collections could do so by employing either kitāb, ğuz or muğallad. The latter two terms not only described a volume or quire belonging to a longer book, but could also refer to one separate (sometimes bound) quire or one of several unrelated quires that were bound together. ${ }^{8}$ This differentiation, especially in a culture with inherently fluid textual formats, raises a number of questions

3 G. Roper: 'The History of the Book'

4 J. Pedersen, The Arabic Book; F. Rosenthal, "'Of Making Books There Is No End"”.

5 S. Günther, 'Praise to the Book!'; Sh. Toorawa, Ibn Abī Țāhir Tayfūr; H. Touati, L'Armoire à sagesse.

6 G. Schoeler, The Genesis of Literature in Islam.

7 For instance B. Messick, The Calligraphic State and M. Kunt 'Reading Elite, Elite Reading'.

$8 \check{G} u z^{\supset} / m u g ̆ a l l a d:$ E. Kohlberg, A Medieval Muslim Scholar, 79. 
with regard to a manuscript's status as book, quire or volume. What exactly was the borderline between a short kitāb and a ğuz ? How did contemporaries deal with composite manuscripts that could contain anything from brief extracts to complete 'books'? To what extent did contemporaries consider multi-volume works with one title to be a single book?

In order to take up these questions, the following discussion turns to documentary evidence of book collections as they offer unique insights into contemporary attitudes to, and understandings of, what a book was. The recently discovered catalogue of a local endowed library in Damascus, the oldest known complete catalogue for an Arabic library, is an appropriate point of entry. ${ }^{9}$ This catalogue documents the holdings of a minor library in the Ašrafiyya Mausoleum, which was situated close to Salāh al-Dīn's resting-place in the city's 'Mausoleum Lane', north of the Umayyad Mosque. ${ }^{10}$ A ruler, the Ayyubid al-Malik al-Ašraf (d. 635/1237), endowed this mausoleum-madrasa, but a member of the civilian elite endowed its library. ${ }^{11}$ The inventory of this library is not dated, but internal evidence, particularly the absence of later authors, indicates that it was produced shortly after the library was set up in the mid-seventh/thirteenth century. The document is fascinating precisely because it does not refer to one of the large-scale prestigious libraries set up by a member of the ruling elite. Rather, it gives an insight into a relatively small library in a somewhat modest institution, dozens of which existed in cities such as Damascus. As this was just an ordinary library, only one contemporary writer mentioned this library in a narrative source. ${ }^{12}$ In contrast to al-Șūlī's library discussed in this volume by Letizia Osti, for which we have only narrative, but no documentary evidence, the source basis for this book collection is thus exactly inversed.

\footnotetext{
9 For the concept of the local endowed library, see my The Written Word, 124-63.

10 Fihrist kutub hizānat al-Ašrafiyya, Fatih 5433, Istanbul, Süleymaniye Library, fols. 246v-270r. The catalogue was briefly mentioned by S. alMunağğid, Qawa $\bar{a}^{c}$ id fahrasat al-mahțūtāt al- ${ }^{c}$ arabiyya, 20/21 (also referred to in A. Gacek, 'Some Remarks', 173) and R. Şeşen, Salahaddin'den Baybars'a, 336. I am currently working on an edition of this document with translation and commentary.

11 The library was endowed by al-Ašraf Aḥmad b. al-Qāḍī al-Fāḍil. On him and further sources cf. al-Dֵahabī: Ta rīh al-islàm, 47 (years 641-50): 149-51.

12 Ibn Khallikān, Wafayāt, I, 214.
} 
The catalogue's writer unequivocally set out the document's function to list 'books' in its heading: 'Catalogue of the Books of the Ašrafiyya Library'. ${ }^{13}$ This document employs a very orderly method to organise the entries that run through its folios - or at least it appears to do so. The first level of this organisational method is the alphabetical order of the titles and lists all entries according to the letters of the alphabet starting with alif and finishing with $y \bar{a}^{3}$. Under each of the letters a second level of organisation subdivides all entries by size, either as a normal or small (sig $\bar{a} r$ ) format. This differentiation was introduced because it presumably reflected the physical set-up of the shelving. Contemporary illustrations of libraries clearly show that shelves were organised according to the size of the manuscripts. ${ }^{14}$ Each of the resulting fifty-six categories (twentyeight letters each with two sections for size) is further subdivided by a third organisational level of subject-matter. For this third level the writer of the catalogue introduced fifteen thematic categories; for instance, category three is Islamic law, category five is history, and category ten is pharmacology and medicine. Thus each entry would potentially have a three-figure class mark in the form of letter/size/subject, such as $\mathrm{A} / \mathrm{s} / 3$ for a book with a title starting with the letter alif, in small format, on Islamic law.

This organisation of the catalogue shows a rather uncomplicated understanding of what a book is: each title has an entry and although many of these titles surely consisted of several volumes this was not of concern for the classification of the library's books. In the early parts of the catalogue we find a numerical system with numbers after many entries that referred to volumes, but this system is silently abandoned after the early folios. The implicit definition underlying this scheme was thus that a book was the entirety of a text belonging to one title, irrespective of whether it came in one or several volumes. Accordingly, the catalogue's writer set out to give each title its own entry. For early entries he also listed each additional copy of the same title as a separate entry. For example, under the letter alif he enumerated: 'al-A $\underline{d} k i y \bar{a}^{\circ}$ by Ibn al-Ğawzī / second copy / al-Amțāl wa-l-hikam by al-Māwardī / second copy / third copy'. ${ }^{15}$ After some folios he was to abandon this system because multiple copies, especially in the case of poetic works which could number well beyond fifteen, made his approach too

13 Fihrist al-Ašrafiyya, fol. 246v: Fihrist kutub hizānat al-Ašrafiyya.

14 Cf. for instance al-Harīin̄, al-Maqāmāt, Paris, BnF, MS arabe 5847, fol. 5v.

15 Fihrist al-Ašrafiyya, fol. 247a. 
cumbersome. Rather, he reverted to state briefly: 'Poetry of Salāma b. Ğandal, fifteen copies'. ${ }^{16}$

However, this one-text-one-title system of cataloguing posed more fundamental challenges than it seems to imply. There are two instances in this document where its orderly organisation almost falls apart entirely as the writer had to accommodate textual units that could not be fully integrated into this text-based definition of the book. The first instance is in the letter $m \bar{l} m$ when the writer came to composite volumes (mağa $\bar{m} \bar{l}^{c}$ ) and the second is in the catalogue's final part where we find what the writer described as 'defective manuscripts' (mahāaīm). In both cases the function of these sections was more complicated than just drawing together manuscripts that were either composite or incomplete. We also find $m a \check{g} \bar{a} m \bar{l}^{c}$ and maharaim-manuscripts in those parts of the catalogue that are structured by the three-tiered method. The writer placed, for example, a collection of sermons (hutab) under the letter $h \bar{a}^{\supset}$ and a number of composite volumes of poetry $\left(\breve{s i} i^{c} r\right)$ under the letter $s \bar{s} n-$ although in the latter case he grouped them at the very end of the letter's section indicating again his uncertainty of where to list them. ${ }^{17}$

Furthermore some composite manuscripts are listed under the letter $m \bar{m}$, but outside the dedicated mağa $\bar{a} \bar{l}^{c}$-section. An anonymous 'Collection of Legal Problems', for instance, is appropriately placed under the letter's normal-sized volumes, subject category 3 (Islamic Law). ${ }^{18}$ Another item containing, amongst others, writings by Galen on phlebotomy is placed under the letter's normal-sized volumes, subject category 10 (pharmacology/medicine). ${ }^{19}$ The mağa $\bar{m} \bar{l}^{c}$ and mahărìmsections were thus not simply formal categories where any manuscript described as composite or defective was to be placed. Rather, they contained works that somehow eluded the three-figure classification of the catalogue. In quantitative terms these sections for composite volumes and defective manuscripts occupy a substantial part of the catalogue. The former runs to more than ten of the catalogue's forty-eight pages and the latter takes up another six pages. In other words a third of the overall collection eluded the catalogue's organisational approach and its implicit text-based definition of the book. ${ }^{20}$

\footnotetext{
16 Fihrist al-Ašrafiyya, fol. 254r.

17 Ibid., fol. 251r: Hutab Mağmiù $\bar{u}^{c}$; fol. 256r: several entries starting with $M a \check{g} m \bar{u}^{c} \check{s} i^{c} r$.

18 Ibid., fol. 258r: Mağm $\bar{u}^{c}$ masa $\bar{a}^{\supset}$ il fiqhiyya.

19 Ibid., fol. 259r.

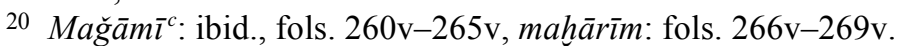


My contention is that the writer's initial certainty with regard to his project of producing a catalogue of this library's 'books' faltered when he faced the collection. The sections for composite volumes and defective manuscripts were desperate attempts to tame the unwieldy material into an orderly list underpinned by a single definition of the book. In order to elaborate on this point I will focus on the section referring to composite volumes, which has a total of 172 entries with well over 500 titles. The first characteristic of this section is that it was not explicitly flagged as one - in contrast to all other sections of the catalogue. The writer had already started to include an increasing number of composite manuscripts on the preceding folios, but at one point, the point which I take to be the beginning of the section, he suddenly began to list composite manuscripts only, without explicitly marking this in any way. ${ }^{21}$ The end of this 'section' is only differentiated by the fact that a new letter starts, nūn, which follows the standard orderly method. Remarkably, the break with the catalogue's system in this part is also reflected in the manuscript's style and ductus: The earlier parts of the catalogue were written in an extremely neat and easily legible hand with clear headings for new categories and ample spaces separating the entries - the writer obviously took great care to represent this splendid collection in an appropriate textual form. Here, however, his script turned hasty, headings were virtually absent and the ample spacing disappeared in an increasingly dense organisation of the text with words running into each other. With the start of the letter nün, however, the writing and the textual organisation resumed its former clarity, probably expressing the writer's relief to have returned to safer shores.

That this composite section contained manuscripts which defied the catalogue's logic of the book as a self-contained textual unit with a more or less stable title, is also evident from the breakdown of the thematic level of organisation. After the writer had, as usual, run through the fifteen categories of the normal-sized manuscripts of the letter $m \overline{i m}$, he turned, as with all other letters, to the small-sized holdings of the library. However, under this letter the system of orderly sections gradually started to unravel as composite books increasingly dominated. In category three, generally preserved for Islamic Law, we now find titles pertaining to the field of poetry that have no relevance to this category such as Questions Asked to al-Mutanabbi Concerning his Poetry, selections from Ibn al-

21 I take the $m a g \check{g} \bar{a} m \bar{\imath}^{c}$-section to start on Fihrist al-Ašrafiyya, fol. $260 \mathrm{v}, 1.9$ : Mağmū $\bar{u}^{c}$ awwaluhu fiqh cala madhab Abī Hanīfa [...] as it is from this point onwards that only mağam $\bar{\imath}{ }^{c}$-works are listed. 
$\mathrm{Mu}^{\mathrm{c}}$ tazz's Generations of the Poets and poetry from the early Islamic poet Dū l-Rumma. ${ }^{22}$ Category five, to cite a second example, normally contains works of history, but under this letter it starts to also include material such as an anonymous Mağmu ${ }^{c}$ of Poetry and Reports. ${ }^{23}$ The writer attempted to secure at least some connection to the History category by including panegyrics on various Ayyubid rulers. After these attempts to keep his system up, he abandoned his efforts and on the following ten pages that make up the composite-volume section he introduced only three further category-headings (seven, eight and nine). This is in sharp contrast to the standard sections of the catalogue where a single page can easily contain up to twenty category-headings or more.

The writer was clearly uncertain of the best strategy to handle these composite manuscripts. He did not introduce a clear section outside his alphabetical organisation to ascribe a particular status to them, nor was he able to fit them convincingly into the existing cataloguing system. Rather, he opted to keep up his scheme, which at this point was no more than fictitious, thus circumventing the challenge posed by the heterogeneous items. The three category headings that he has in this section bear little relation to the actual content of the manuscripts listed under them. This is again in striking contrast to the rest of the catalogue where the link between subject-matter and category heading is generally reasonably close. Furthermore, in this section the writer abandoned his system of differentiating the manuscripts according to size - it is at least very unlikely that all of the items listed on these pages were indeed smallsized, as the catalogue implies.

The challenges posed by these items in comparison to the normal onetext-one-title books were indeed considerable. For instance, within category nine, where we would normally expect writings on astronomy/astrology and oneiromancy, one composite manuscript includes, amongst others, the following works: (1) Ibn Durayd's (d. $321 / 933$ ) poem on words ending in alif (2) a treatise on rhymes, arguably by Ibn Ğinnī (d. 392/1002) (3) a hadịt-treatise by Ibn Šāhīn (d. 385/995) (4) a treatise on the prayers of supplication during Ramadan (5) a treatise on metrics (6) Ibn Fāris's (d. 395/1004?) collection of juridical riddles based on a rare meaning of a word (7) a selection of passages from the same work (8) historical reports (9) al-Zağğăğg's (d. 311/923) work of philology and lexicography detailing the Arabic terms for human

22 Fihrist al-Ašrafiyya, fol. 260r: Masā̄il sủila ${ }^{c} a n h \bar{a}$ al-Mutanabbī min

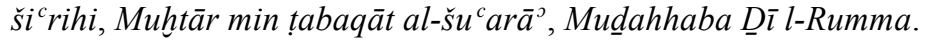

23 Ibid., fol. 261r/v: Mağmū $\bar{u}^{c}$ ašc $\bar{a} r$ wa-ahbār muğallad. 
anatomy (10) al-Rummān̄̄s (d. 384/994) treatise on the uniqueness and inimitability of the Qurª̄n, and (11) five hadīt-dictations by Abū Țāhir al-Salafī (d. 576/1180). ${ }^{24}$ While the categories that the writer had drawn up covered the subject matter of the items within this entry, the composite item as a whole completely defied them.

The overall range of the material that the writer brought together in this section becomes more evident when we draw from a number of composite works: in addition to pre-Islamic and early Islamic poetry as well as philological texts (both great favourites of the founder of the Ašrafiyya Library in all sections), we find for instance the testaments of ${ }^{\mathrm{c}}$ Alī b. Abī Țâlib to his son al-Ḥusayn and of the Sassanian ruler Ardašīr to his descendants/his son Šāpūr; al-Hwārizmī’s fourth/tenth-century treatise on the classification of sciences; a treatise on geomancy; Greek medical treatises on the symptoms of imminent death; a collection on amulets and talismans; a treatise on the excellence of horses; selected items on jurisprudence, followed by a poem on the number of Quranic verses and sermons, poetry in Persian; fourth/tenth-century pharmacological treatises by al-Rāzī; the bacchanalian poetry of Abū Nuwās and Ibn al-Muqaffa ${ }^{\text {c's }}$ s mirror for princes..$^{25}$

The cataloguer's problem was that he had started out with the confident statement that this was the 'Catalogue of the Books of the Ašrafiyya Library'. His organisation was based on the understanding that a book was simply a textual unit that could be catalogued under one specific title - and at first, this strategy had been entirely adequate. As seen, it was not a main concern for him whether this text was contained in a single volume or spread over several volumes. His abandonment of the numerical system for volumes after the initial folios was not a major change which undermined either the catalogue's basic structure or the underlying definition of the book. The physical appearance of the

24 Fihrist al-Ašrafiyya, fol. 265r: Mağmūc Qașìd Ibn Durayd fì l-maqșūr wa-lmamdūd wa-Muhtașar qawāfì wa-Mā qaruba isnāduhu li-Ibn Šāhīn [...] wa-Ṣalāt al-rag $\bar{a}^{\top} i b$ wa- ${ }^{c}$ Arū Halq al-insān li-l-Zağğăğ [...] wa-Nukat al-Rummān̄̄ [...] wa-Hamsa min amālì al-Salafi.

25 Ibid., fol. 260v: wașiyat ${ }^{c}$ Alì $b$. Abī Țālib li-waladihi al-Husayn rạ̣iya Allāh 'anhumā, 261r: 'Ahd Ardašìr, 261r: Mafātīh al- ${ }^{c} u l u ̄ m, ~ 261 \mathrm{v}:$ Sirr alșināc a fi l-raml, fol. 262r: 'Alāmāt al-mawt, fol. 262r: Mağmū ${ }^{c}{ }^{c} u w a \underline{d} w a-$

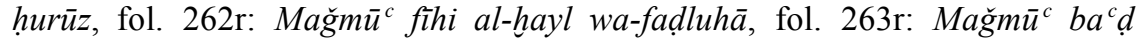
muhtār fiqh wa-qașid fì cadad āy al-Qur ${ }^{c} \bar{a} n$ wa-mawa ${ }^{c} i z$, fol. 263r/264r: $A \check{s}^{c} \bar{a} r$ bi-l-" ağamī, fol. 263r: Mağmū ${ }^{c}$ li-l-Rāzì Abdāl al-adwiya [...], fol. 163v: Hamriyyāt Abī Nuwās, fol. 264r: Ādāb al-wuzarā ${ }^{\text {. }}$. 
manuscripts was of concern only when it came to their size, the second level of the catalogue's organisation. For the catalogue's organisation though, as far as the present discussion is concerned, the size of the manuscripts was irrelevant.

Yet, the simple assumption of a text-based definition of the book hit the wall midway through the catalogue and proved impossible for around a third of the collection. The alphabetical organisation became useless at this point as it did not allow the catalogue's users to identify specific texts, the thematic categories were impossible to impose on this material and even the normal/small-size differentiation fell by the wayside. The writer adopted for this material a new definition of 'book', which was based on its physical shape, in other words he devoted an entry to each collection of folios that was bound together, irrespective of title, theme or size. This shift to a physical definition is also evident in the writer's exasperation when he repeatedly cut short the description of a volume's content with a brief 'and other [texts] than this' ${ }^{26}$ Clearly, it was the physical shape of the book that had become his main concern in this section, and he could thus circumvent the daunting task of thematically classifying the content - an approach that would have been untenable in the catalogue's other sections.

This shift in definition allowed the writer to keep up the appearance of a catalogue that progressed neatly entry by entry. Fundamentally, this combination of a text-based and a volume-based definition of the book was untenable - and arguably the changing styles of writing and presenting the material indicated that the writer himself felt uneasy with his solution. However, it was a useful solution to resolve this writer's struggle to find order in a collection of 'books' that would not match one single definition. The writer was not able to 'catch the eel', but he was at least able to use the elusiveness of the definition to his own advantage as he preserved the illusion of a single scheme for the heterogeneous material that he found on the shelves. The main legacy of this seventh/thirteenth-century writer and his cataloguing practices for our purposes is to remind us that the term 'book' is far from a commonsense term, not only for the Formative Period, but also in subsequent centuries. Though the term kitāb could not mean all things to all men, it could at least mean quite different things to those dealing with the written word in this phase of Arabic manuscript culture.

${ }^{26}$ For instance, Fihrist al-Ašrafiyya, fol. 261v, 1. 2, 1. 14; 262r, 1. 1, 1. 3, 1. 8/9, 1. 16; fol. 262v, 1. 14, 1. 18/19; fol. 263r, 1. 16; fol. 163v, 1. 5. 


\section{BIBLIOGRAPHY}

Primary sources

Al-Dahabī, Ta ${ }^{\top} r \bar{r} h$ al-islām wa-wafayāt al-mašāhīr wa-l-a ${ }^{c} l \bar{a} m$, ed. ${ }^{~} \mathrm{U}$. Tadmurī, 52 vols. (Beirut: Dār al-kitāb al-- ${ }^{c}$ arabīi, 1987-2000).

Fihrist kutub hizānat al-Ašrafiyya, Fatih 5433, Istanbul, Süleymaniye Library, fols. 246v-270r.

Al-Ḥarīīi, al-Maqāmāt, Paris, BnF, MS arabe 5847.

Ibn Khallikān, Wafayāt al-a yānn wa-abnāo al-zamān, ed. I. ' Abbās, 8 vols. (Beirut: Dār al-thaqāfa 1968-72, reprint Beirut: Dār șādir).

Luther, Martin, Luther's Works, Tappert, T.G. (ed. and tr.), vol. 54: Table Talk (Philadelphia: Fortress Press, 1967).

Secondary studies

Gacek, Adam, 'Some Remarks on the Cataloguing of Arabic Manuscripts', British Society for Middle Eastern Bulletin 10 (1983), 173-9.

Günther, Sebastian, 'Praise to the Book! Al-Jāhiz and Ibn Qutayba on the Excellence of the Written Word in Medieval Islam', Jerusalem Studies in Arabic and Islam 32 (2006), 125-43.

Hirschler, Konrad, The Written Word in the Medieval Arabic Lands: A Social and Cultural History of Reading Practices (Edinburgh: Edinburgh University Press, 2012).

Housley, Norman, Contesting the Crusades (Malden, Mass.: Blackwell, 2006).

Kohlberg, Etan, A Medieval Muslim Scholar at Work: Ibn Tâ̄wūs and His Library (Leiden: Brill, 1992).

Kunt, Metin, 'Reading Elite, Elite Reading', in P. Sadgrove (ed.), History of Printing and Publishing in the Middle East (Oxford: Oxford University Press on behalf of the University of Manchester, 2008).

Messick, Brinkley, The Calligraphic State. Textual Domination and History in a Muslim Society (Berkeley: University of California Press, 1993), 89-99.

Al-Munağğid, Șalāḥ al-Dīn, Qawā ${ }^{c} i d$ fahrasat al-mahtūtụt al- ${ }^{c}$ arabiyya (Beirut: Dār al-kitāb al-ğadīd, 1976).

Pedersen, Johannes, The Arabic Book, tr. G. French; ed. and intr. R. Hillenbrand (Princeton, N.J., Princeton University Press, 1984).

Roper, Geoffrey, 'The History of the Book in the Muslim World', in M. Suarez and H. Woudhuysen (eds.), The Oxford Companion to the Book (Oxford: Oxford University Press, 2010), 321-39. 
Rosenthal, Franz, “"Of Making Books There Is No End": The Classical Muslim View' in G. Atiyeh (ed.), The Book in the Islamic World. The Written Word and Communication in the Middle East (Albany: State University of New York Press, 1995), 33-55.

Schoeler, Gregor, The Genesis of Literature in Islam: From the Aural to the Read, tr. and coll. Shawkat Toorawa (Edinburgh: Edinburgh University Press, 2009).

Şeşen, Ramazan, Salahaddin'den Baybars'a: Eyyubiler-Memluklar (1193-1260) (İstanbul: İslâm Tarih, Sanat ve Kültürünü Araştırma Vakfi, ISAR 2007).

Toorawa, Shawkat, Ibn Abī Țāhir Tayfür and Arabic Writerly Culture. A Ninth-Century Bookman in Baghdad (London: RoutledgeCurzon, 2005).

Touati, Houari, L'Armoire à sagesse. Bibliothèques et collections en Islam, (Paris: Editions Aubier, 2003). 